\title{
PROPAGATION AND CONSERVATION GERMPLASM OF LEMONGRASS (CYMBOPOGON CITRATUS STAPF) THROUGH BIOTECHNOLOGY TECHNIQUES
}

\author{
Héctor Rafael Peralta Corona*, Maximo Mejia Rosario and Jose Diaz Trinidad \\ Institute of Innovation in Biotechnology and Industry (IIBI). P. O. Box 329-2. Santo Domingo. Dominican Republic \\ Ministry of Higher Education, Science and Technology (MESCYT)/ National Fund for Innovation in Scientific and \\ Technological Development (FONDOC YT)
}

\author{
https://doi.org/10.35410/IJAEB.2020.5464
}

\begin{abstract}
Cymbopogon citratus and Cymbopogon nardus are two species of lemongrass very useful because they have analgesic, anti-inflammatory, and hypotensive properties, used in the development of popular medicines. Three experiments were carried out: organogenesis, embryogenesis and in vitro conservation, achieving with these tools the establishment in vitro. In the organogenesis three types of tissues were used: nodal segments, meristematic apices and meristems. In embryogenesis, three 2,4-dichloro phenoxyacetic acid (2,4-D) $(0,2.0,2.5,3.0 \mathrm{mg} /$ L) proteins were used in the culture medium. For in vitro preservation, four mannitol proteins ( 0 , $10,20,30 \mathrm{mg} / \mathrm{L}$ ) were used in the culture medium. The results establish the in vitro establishment of C. citratus and C. nardus through biotechnological techniques. Outbreaks survived in all treatments of organogenesis, embryogenesis and in vitro conservation of lemongrass, produced roots and proteins $85 \%$ survival during the acclimatization stage. The acclimatized plants obtained a vigorous appearance and developed normally when they were transferred to the soil. The vitroplants were preserved in vitro under conditions of slow growth affected by mannitol, which retarded growth without affecting survival.
\end{abstract}

Keywords: organogenesis, embryogenesis, Cymbopogon citratus and Cymbopogon nardus.

\section{INTRODUCTION}

Lemongrass (Cymbopogon citratus (D. C.) Stapf.) From the Poaceae (Graminae) family, is a plant native to Southeast Asia and stores in its parenchymal cells an essential oil called yellowish citronella rich in substances of great interest. This oil has citral as its main components, approximately $80 \%$ in the form of its two isomers: neral $33.5 \%$ and geranial $45.9 \%$, and myrcene $12.8 \%$ (Chalchat et al; 1997), from which can be synthesized several substances of industrial application. Lemongrass is also carminative, digestive and is used for the treatment of flatulence. Scrubbing its leaves through the teeth prevents tooth decay. In infusion it is used as an aromatic and febrifuge tonic. It is used in Asian cuisine, especially in Thai cuisine. (Watson and Dallwitz, 2008). The members of the genus Cymbopogon stand out for their content of essential oils, which vary in their composition and concentration depending on the species and the growing conditions of the crops (Wijesekera, 1981; Rao and Sunita, 1992; Chisowa et al; 1998 ; Rhaman et al; 1992; Kulcarni et al; 1997), cited by Antolinez et al; 2008). 
Scientists from the University of Kyoto, Japan, concluded that the essential oil of Cymbopogon citratus fully demonstrated its effectiveness against the Helicobacter pylori bacteria, without such bacteria exhibiting resistance to treatment with this essential oil (Watson and Dallwitz, 2008). Mohd et al; (2010) demonstrated that gram-negative organisms with high resistance to different antibiotics were inhibited with Cymbopogon citratus oil still in low concentration. These authors suggest that the use of this oil would be helpful in the treatment of infections caused by these organisms.

Essential oils are volatile products of complex chemical composition widely spread in the plant kingdom (Mizrahi, 1967; Bruneton, 1999; Bandoni, 2000) cited by Antolinez et al; 2008). In the essential oil of C. citratus predominates citral aldehyde (mixture of geranial and neral) reaching concentrations of 75\% (Quintero et al; 1999, 2000; González, 2003) cited by Antolinez et al; 2008). Citral is a precursor to ionones, vitamin A, methylionone and citronellol (Theaganajar and Kumar, 1995; Wijeskera, 1981). These secondary metabolites are extracted from plants by various methods according to their nature and the plant organ where they are found; Thus, for example, citrus peel oil can be extracted by mechanical pressing and steam entrainment, others are extracted by means of solvents, applying supercritical fluids and, in the case of C. citratus, it is advisable to carry out extraction by hydrodestilation ( Mizrahi, 1967; Bandoni, 2000; Ming et al; 2000) cited by Antolinez et al; (2008).

The trade of medicinal plants requires that a good proportion of the plant material come from the crop; A high demand is destined to the pharmaceutical industry and also, although in smaller volume, there is a certain request from the condiments and cosmetology industries, so these plants are of great importance due to the social impact they have, especially on health (Antolinez et al; 2008).

In our country Dominican Republic, lemongrass (Cymbopogon citratus) despite its high demand is not found in the wild and rarely see some plants planted in courtyards and residential gardens, there are no commercial plantations according to Dr. Vasquez Tineo, (Personal Communication, 2010), so it is urgent to implement programs for cultivation, conservation and rational use of this therapeutic resource. Given the difficulty of propagating the lemongrass in our country, the normal multiplication procedure is vegetative. The in vitro culture technique is an excellent alternative for the multiplication and conservation of lemongrass. This also allows obtaining a large number of plants in a small space and under controlled conditions that prevent the transmission of diseases. It is a very useful tool in breeding programs, since it has the potential to produce plants of uniform quality on a commercial scale, from a select genotype and with an unlimited multiplication rate (Olmos et al; 2004).

In our country there are not known studies on tissue cultures of these species, therefore, it is essential to stimulate in vitro regeneration and mass propagation of lemongrass plants to solve the problem of scarcity of these species. Hence the importance of being able to preserve it in vitro and ex situ and establish commercial plantations of said plant in the field to produce the raw material demanded by the pharmaceutical and herbal industries for the production of both medicinal and cosmetic products and in this way, it would be ensuring the preservation of this 
species, as well as being a source of jobs and currency generation for the country. It is necessary through research to define the technical elements of an appropriate process of adaptation of lemongrass, which will determine its success and as an indispensable thing the ability and knowledge of the individual to handle in vitro and agricultural techniques and implement methodological processes With the different stages. Hence the general objective of this research was to use biotechnological tools to propagate and conserve lemongrass (Cymbopogon citratus).

\section{MATERIALS AND METHODS}

\subsection{Research Location}

This research was carried out at the Center for Plant Biotechnology (CEBIVE) of the Institute of Innovation in Biotechnology and Industry (IIBI). The collection of plant material began in the northern regions (Santiago de los Caballeros), Eastern region (Hato Mayor) and in Santo Domingo, D. N. Two species of lemongrass were used in this investigation: Cymbopogon citratus and Cymbopogon nardus. This project corresponds to the objective of the national plan Science Innovation and Technological Development. It fits with the area of applied sciences, with the subprograms of biotechnology, genetic resources, environmental programs and natural resources and in turn with two subprograms of plant and biodiversity biotechnology.

\subsection{Plant Material Asepsis}

The asepsis of the material was performed following the protocols of Mohd et al; (2010) and Cetz, (2005): the material was washed with distilled and sterilized water and liquid soap for five minutes, then immersed in $70 \%$ alcohol for a period of minute. It was then introduced into a solution of $1.58 \%$ Sodium Hypochlorite active ingredient of the commercial concentration, for 30 minutes. The material was then introduced into a fungicidal / bactericidal solution (Mastercop 25SC) for 30 minutes under constant stirring in a shaker. In each process four rinses were made with distilled and sterilized water.

\subsection{Organogenesis Process}

In a laminar flow cabinet, three types of tissues were extracted from the two lemongrass species: nodal segments, meristematic apices and meristems to be sown in the corresponding culture media. In this phase, the three types of tissues for plant regeneration were compared. In the case of meristem culture, a stereoscopic magnifying glass was used for the extraction of meristematic tissue. The culture medium used by Licea et al; (2001) was initially used in the in vitro multiplication of Cymbopogon citratus by organogenesis, composed of the salts Murashige and Skoog (1962); and supplemented with $1.0 \mathrm{mg} / 1$ of thiamine; $100 \mathrm{mg} / 1$ of myoinositol; $0.3 \mathrm{mg} /$ 1 of 6-BAP and $30 \mathrm{mg} / 1$ of sucrose, solidified with $6.3 \mathrm{~g} / 1$ of agar. Subsequently, the plant material was transferred to light under a photoperiod of 16 light hours, temperature of $25 \pm 2{ }^{\circ} \mathrm{C}$ and light intensity of 3,000 lux. The same culture medium of Licea et al; (2001) was also used in the temporary immersion system where the plants obtained by organogenesis were multiplied massively. From each material, the quantity of plants obtained, their length, number of leaves and the multiplication coefficient were evaluated. 
Vol. 5, No. 01; 2020

ISSN: $2456-8643$

\subsection{Somatic Embryogenesis Process}

For somatic embryogenesis, vitroplants obtained by organogenesis and multiplied in the temporary immersion system were used. The leaves were sectioned in an approximate diameter of $0.5 \mathrm{~cm}$ and inoculated in the MS medium used in sugarcane by Cuéllar, (1997), as follows: macronutrients $20 \mathrm{mg} / \mathrm{L}$, micronutrients $10 \mathrm{mg} / 1$, sucrose $20 \mathrm{mg} / \mathrm{L}$, myoinositol $100 \mathrm{mg} / \mathrm{L}$, thiamine $1.0 \mathrm{mg} / 1$ and 2,4-D $3.0 \mathrm{mg} / \mathrm{L} .100 \mathrm{mg} / \mathrm{L}$ of Ascorbic acid will be added to the culture medium to minimize tissue phenolization. This medium was used for callus formation. After forming the calluses, these were transferred to the same MS nutrient media, but with different concentrations of 2,4-D-dichloro phenoxyacetic acid (2,4-D) $(3,0 ; 2,5 ; 2,0$ and $0 \mathrm{mg} /$ $\mathrm{L}$ ), for their growth and development. Then the calluses of the different treatments with 2,4-D were placed in MS medium without growth regulators for differentiation of tissues and obtaining seedlings. For rooting the seedlings, $5 \mathrm{mg} / \mathrm{L}$ of AIA was added to the MS culture medium. Variants of the culture medium containing 2,4-D were compared and the number of calluses, number of shoots per callus, seedlings produced per callus and their length will be evaluated.

\subsection{Conservation}

Two germplasm banks of both lemongrass species will be developed, in vitro (IIBI) and ex situ (Botanical Garden). For the in vitro conservation the protocol of García et al; (2004) used in sugar cane will be used, using the medium of Murashige and Skoog (1962) at 50\% of its concentration, complemented with different concentrations of mannitol $(0,10,20$, and $30 \mathrm{mg} /$ L). During the conservation period the behavior of the plants in the different treatments will be observed and at 12 months the survival percentage will be determined, as well as the growth and plant development determined by the height and the number of shoots per plant. For the establishment of the ex situ germplasm bank of the acclimatized plants of both lemongrass species, the National Botanic Garden will use among other protocols that of (Wyse Jackson \& Sutherland, 2000) and (BGCI, 2000) and the Roig agrotechnical instructional protocol , (2002).

\subsection{Acclimatization Process}

For the acclimatization process of the plants in vitro, the following procedure was performed: a) transfer to a sterile peat-perlite substrate (1: 1), for 30 days and b) transfer to pots in a greenhouse with a substrate of equal proportion as in the previous phase, with relative humidity of $80-100 \%$, following the protocol of Matos (2007). The regenerated plants of both species were transplanted in plastic trays with individualized holes and then were sown in the field following the technical instructions of Roig, (2002) for the cultivation of Cymbopogon citratus and the establishment of the germplasm bank in situ.

\subsection{Experimental Design}

In the experiment randomly, for a total of 60 experimental units. In the organogenesis protocol, a randomized complete design with $3 \times 2$ factorial arrangement (3 types of tissues and 2 lemongrass species) was used with 10 repetitions per treatment distributed somatic embryogenesis another randomized complete design with $4 \mathrm{x}$ factorial arrangement was used 2 
(4 variants of culture media and 2 species of lemongrass) with 10 repetitions for 80 experimental units and finally, in the in vitro conservation test the same design was used with a $4 \times 2$ factorial arrangement (4 culture media and 2 species of lemongrass with 10 repetitions per treatment for a total of 80 experimental units In all experiments, the Tukey test at 5\% error was used to detect the differences between the means of the treatments Variance analyzes were performed for the different data obtained using the SAS statistical program, version 8.1.

\section{RESULTS AND DISCUSSION}

The cultivation of plant tissues, is a set of techniques that allow the cultivation in aseptic conditions of organs, tissues, cells and protoplasts using artificial nutritional means. There are two fundamental routes used in the in vitro regeneration of plants: organogenesis and somatic embryogenesis. Organogenesis generally occurs by optimization of the cytokinin-auxin ratio in the culture medium, and occurs by the difference of organs and outbreaks directly from the explant or callus, being able to organize a single cell or a set of cells, which It is characterized by being a unipolar structure with a wide vascular connection of the organs formed with the explant (Jiménez, 1998).

Somatic embryogenesis in the cultivation of plant tissues is the process of initiation of a somatic embryo and its development from vegetative or non-gamnetic cells (Simões et al; 2010). With this technique, morphologically normal somatic embryos are produced, without somaclonal variation and with the ability to germinate and become plants quickly and efficiently (Parrott, 2002).

Different growth regulators can be used to induce organogenesis in different types of explants, usually auxin growth regulators combined with cytokinin growth regulators. To induce embryogenesis, auxins are usually used and in particular 2-4 D (2-4 dichlorophenoxyacetic acid). However, in each case, regulators are required at certain concentrations that are determined empirically.

\subsection{Establishment of Lemongrass Via Organogenesis}

Variance analyzes showed significant differences $(\mathrm{P}<0.05)$ between the two species and the three types of lemongrass materials in the different variables evaluated (Table 3.1).

\subsection{Number of Plants by Species and Type of Material}

The average number of plants obtained in the species Cymbopogon nardus (5.07) with a length of $4.38 \mathrm{~cm}$ was statistically higher than that obtained in the species Cymbopogon citratus (3.77) and length of $3.32 \mathrm{~cm}$. Regarding the amount of leaves / plant C. Nardus obtained 3.73 and C. Citratus 3.12. For the multiplication coefficient in both species (C. Nardus and C. Citratus) the means of 1.57 and 1.29 were equal statistically (Table 3.1).

As for the types of materials, the amount of plants obtained by meristems was higher (7.55) than those obtained by the nodal segments (3.25) and meristematic apices (2.45), but in the length of the plants the average obtained by the apexes meristematic (4.65) was superior to those obtained by meristems (3.82) and meristematic apices (3.75). For the mean number of leaves / plant and 
Vol. 5, No. 01; 2020

ISSN: $2456-8643$

multiplication coefficient, no significant differences were found between the types of lemongrass materials (Table 3.1).

Licea y Col. (2001) en Cuba, lograron el establecimiento y multiplicación in vitro de la Caña Santa (Cymbopogon citratus) de ápices meristemáticos por organogénesis, obteniendo un promedio de 3.43 yemas axilares en los explantes. Este resultado fue inferior al obtenido en la presente investigación (7.55). En Japón, a través de la propagación in vitro del limoncillo (Cymbopogon citratus), Mizukami y Col. (1988) sembraron ápices meristemáticos en el medio de cultivo basal LS para inducir la brotación de yemas obteniendo la mayor cantidad de yemas (16) siendo superior a los obtenidas en esta investigacion empleando el medio MS..

Table 3.1 Individual effect of Species and Type of material on Lemongrass Organogenesis Specie Material Plant Plant Leaf/plant Multiplication number lengh $(\mathrm{cm}) \quad$ coefficient

\begin{tabular}{|c|c|c|c|c|}
\hline tratus & $3.77 \pm 0.33 b$ & $4.38 \pm 0.19 \mathrm{a}$ & $3.73 \pm 0.14 \mathrm{a}$ & $1.57 \pm($ \\
\hline Irdus & $5.07 \pm 0.33 \mathrm{a}$ & $3.32 \pm 0.19 b$ & $3.12 \pm 0.25 b$ & $1.29 \pm 0.10 \mathrm{a}$ \\
\hline Meristem & $7.55 \pm 0.40 \mathrm{a}$ & $3.82 \pm 0.23 \mathrm{a}$ & $3.43 \pm 0.18 \mathrm{a}$ & $1.61 \pm 0.12 \mathrm{a}$ \\
\hline Nodal Segment & $3.25 \pm 0.40 \mathrm{~b}$ & $3.75 \pm$ & $3.59 \pm 0.18 \mathrm{a}$ & $1.46 \pm 0.12 \mathrm{a}$ \\
\hline Meristemátic Apice & $2.45 \pm 0.40 \mathrm{~b}$ & $3.99 \pm 0.23 \mathrm{a}$ & $3.27 \pm 0.18 \mathrm{a}$ & $1.22 \pm 0.12 \mathrm{a}$ \\
\hline
\end{tabular}

On the other hand, it can be seen from Table 4.2 that the means of the number of plants between the materials and the species ranged from 2.30 to 9.40 , with the nodal segments of $\mathrm{C}$. Nardus reaching the highest number of plants (9.40) followed by meristems in the species C. citratus with 5.70 plants (Figure 3.1). In contrast, the meristematic apexes of C. mardus obtained the greatest length of the plants with $6.15 \mathrm{~cm}$, there being no significant differences between the other materials of the two species under study. In the number of leaves / plant the nodal segments of C. nardus obtained the highest mean (3.83), the other means being statistically equal, except for meristematic apices of C. Citratus with the lowest average of 2.78 leaves / plant. In the multiplication coefficient there were no significant differences between the means for the different types of materials of both lemongrass species (Figures 3.1, 3.2, 3.3 and 3.4). 
Table 3.2. Effect of Material Type on Lemongrass Organogenesis

$\begin{array}{llll}\text { Plant } & \text { Plant } & & \text { multiplication } \\ \text { number } & \text { lengh }(\mathrm{cm}) & \text { Leaf/plant } & \text { coefficient }\end{array}$

Specie Material

$\begin{array}{llllll}\text { Citratus } & \text { AM } & 2.60 \pm 0.56 \mathrm{a} & 3.15 \pm 0.32 \mathrm{a} & 2.78 \pm 0.25 \mathrm{a} & 1.10 \pm 0.17 \mathrm{a} \\ \text { Citratus } & \text { SN } & 3.00 \pm 1.56 \mathrm{a} & 3.49 \pm 0.32 \mathrm{a} & 3.35 \pm 0.25 \mathrm{ab} & 1.22 \pm 0.17 \mathrm{a} \\ \text { Citratus } & \mathrm{M} & 5.70 \pm 1.56 \mathrm{~b} & 3.33 \pm 0.32 \mathrm{a} & 3.23 \pm 0.25 \mathrm{ab} & 1.56 \pm 0.17 \mathrm{a} \\ \text { Nardus } & \text { AM } & 2.30 \pm 1.56 \mathrm{a} & 6.15 \pm 0.32 \mathrm{~b} & 3.75 \pm 0.25 \mathrm{ab} & 1.34 \pm 0.17 \mathrm{a} \\ \text { Nardus } & \mathrm{SN} & 3.50 \pm 0.56 \mathrm{ab} & 4.01 \pm 0.32 \mathrm{a} & 3.83 \pm 0.25 \mathrm{~b} & 1.70 \pm 0.17 \mathrm{a} \\ \text { Nardus } & \mathrm{M} & 9.40 \pm 0.56 \mathrm{c} & 4.31 \pm 0.32 \mathrm{a} & 3.62 \pm 0.25 \mathrm{ab} & 1.66 \pm 0.17 \mathrm{a}\end{array}$

Stockings with a common letter are not significantly different ( $\mathrm{p}>0.05)$.

$\mathrm{AM}=$ Meristemátic Apice

SN= Nodal Segment

$\mathrm{M}=$ Meristem

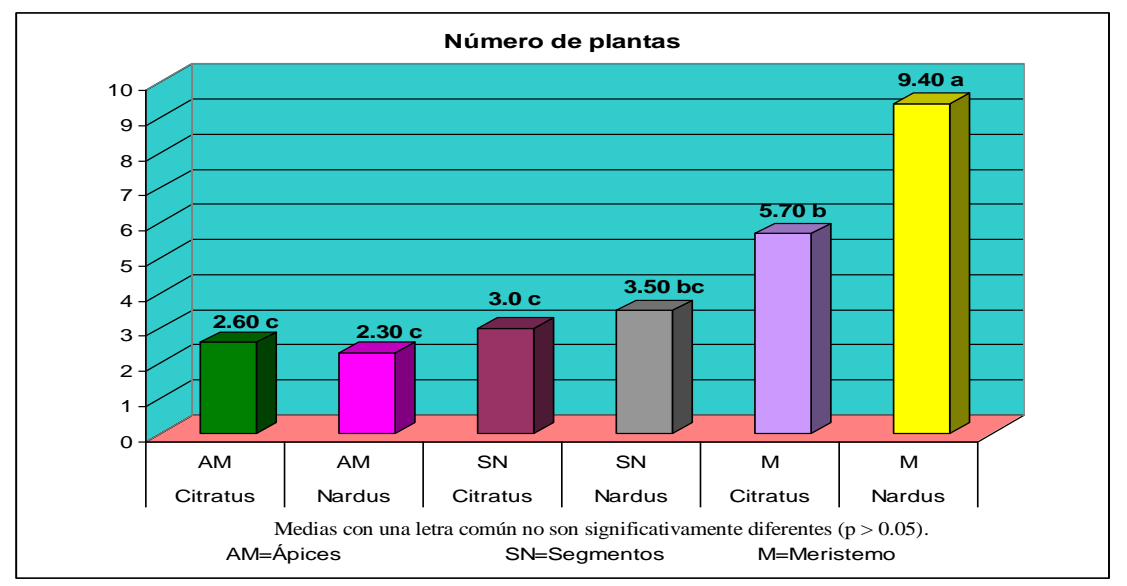

Figure 3.1 Influence of the Number of Plants on the Species and Types of Lemongrass Materials. 


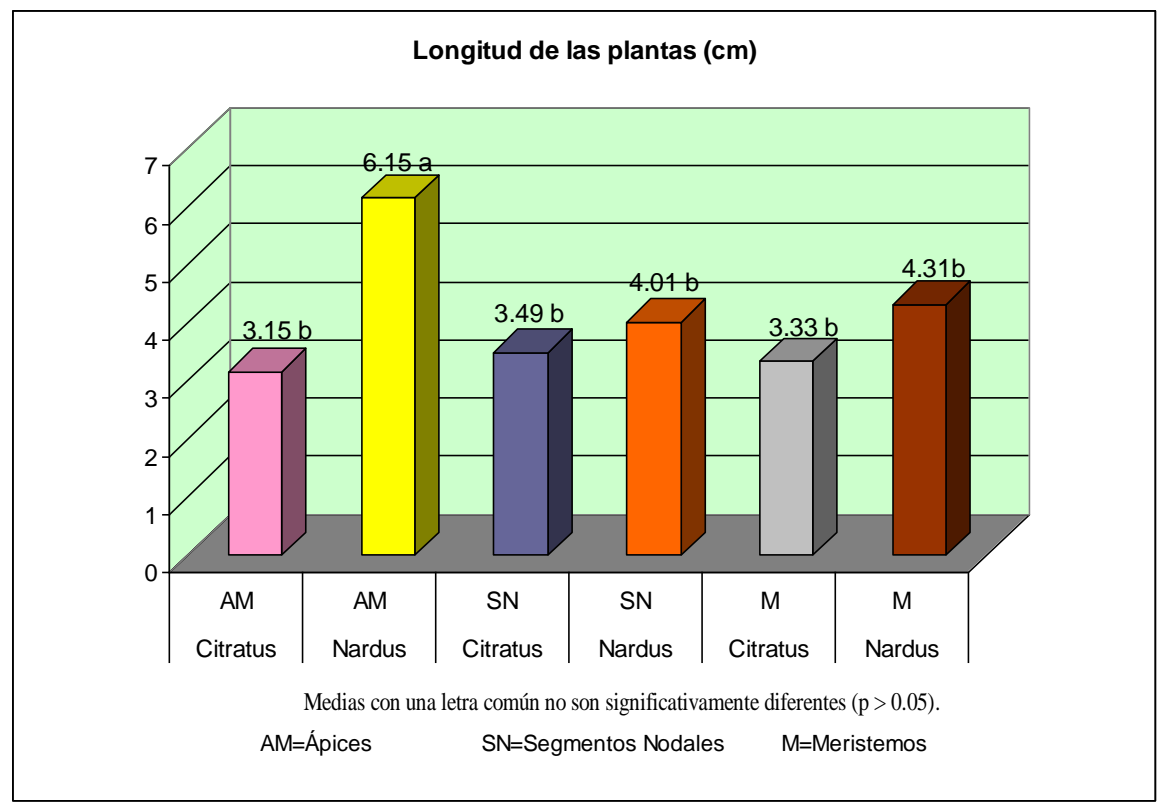

Figure 3.2 Influence of Plant length on Species and Types of Lemongrass materials.

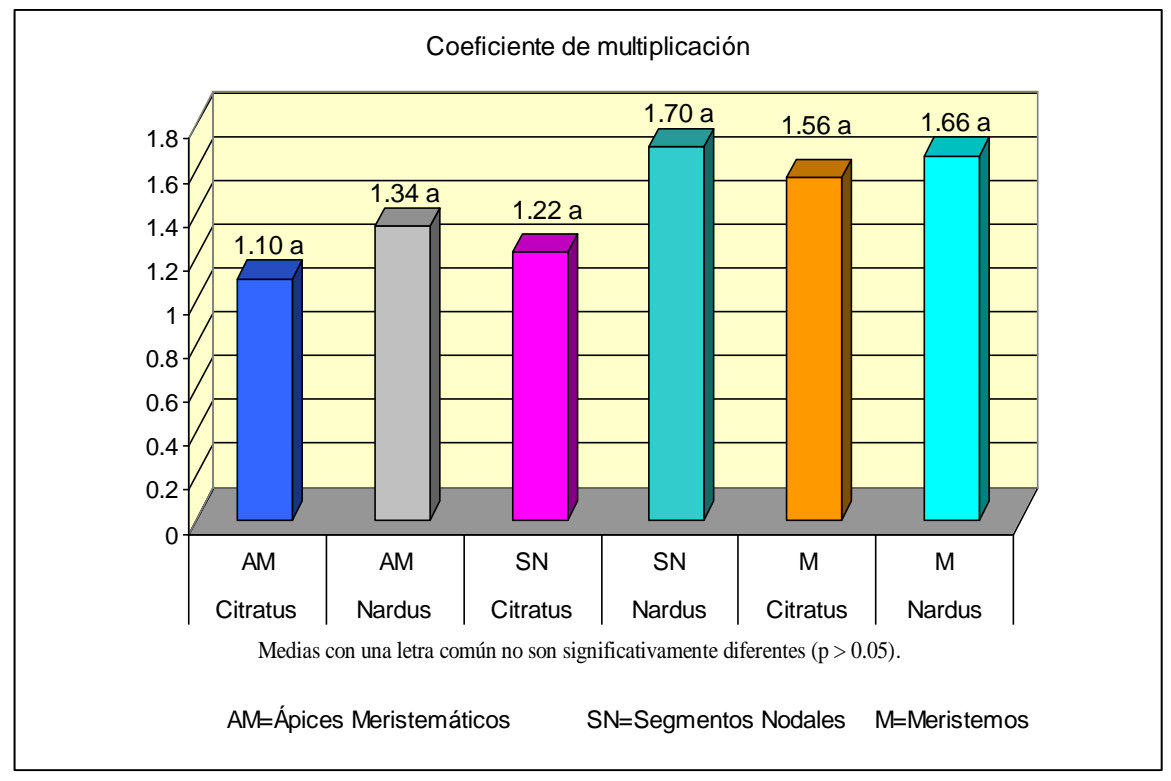

Figure 3.4 Influence of the Multiplication Coefficient of Plants on Species and Types of Lemongrass Materials. 
Vol. 5, No. 01; 2020

ISSN: $2456-8643$

\subsection{Lemongrass Somatic Embryogenesis}

Somatic embryogenesis in the cultivation of plant tissues is the process of initiation of a somatic embryo and its development from vegetative or non-gamnetic cells (Simões et al; 2010). With this technique, morphologically normal somatic embryos are produced, without somaclonal variation and with the ability to germinate and become plants quickly and efficiently (Parrott, 2002).

In the analysis of variance there are significant directions $(\mathrm{P}<0.05)$ between the species, while in the culture media there were highly significant differences between their means (Annex 2). In the separation of means by Tukey, somatic embryogenesis in lemongrass was higher in the nardus species, reaching an average of 1.55 corns, while the citratus species obtained a lower value of 1.05 corns. This last species exceeded the nardus species in terms of the number of shoots (2.03) regenerating 1.28 plants with an average length of $1.02 \mathrm{~cm}$, while the shoots produced by $\mathrm{C}$. nardus (098) regenerated an average of 1.20 plants with length $(2.02 \mathrm{~cm})$ higher than that obtained by C. citratus (Table 3.3).

In the culture media the control (M1) without the presence of 2,4-D did not regenerate calluses for the formation of somatic embryos, while the medium (M4) with $3.0 \mathrm{mg} / \mathrm{L}$ of 2,4-D was the treatment which produced greater amounts of calluses (3.50), shoots (3.45) and plants (5.30) with the greatest lengths $(3.01 \mathrm{~cm})$, thus exceeding the means $\mathrm{M} 3$ and $\mathrm{M} 2$ which were supplemented with 2.5 and $2.0 \mathrm{mg} / \mathrm{L}$ of 2, 4-D, respectively (Table 3.4).

Table 3.3. Effect of 2,4-D on Lemongrass Embryogenesis according to Species and Culture Media.

\begin{tabular}{|c|c|c|c|c|c|c|}
\hline Specie & $\begin{array}{l}\text { Media } \\
\text { culture }\end{array}$ & $\begin{array}{l}2,4-\mathrm{D} \\
(\mathrm{mg} / \mathrm{L})\end{array}$ & $\begin{array}{l}\text { Number of } \\
\text { calluses }\end{array}$ & $\begin{array}{l}\text { Number of } \\
\text { shoots }\end{array}$ & $\begin{array}{l}\text { Number of } \\
\text { plants }\end{array}$ & $\begin{array}{l}\text { Plant } \\
\text { lengh }(\mathrm{cm})\end{array}$ \\
\hline Citratus & & & $1.05 \pm 0.15 b$ & $2.03 \pm 0.19 a$ & $1.28 \pm 0.30 \mathrm{a}$ & $1.02 \pm 0.17 b$ \\
\hline \multirow[t]{5}{*}{ Nardus } & & & $1.55 \pm 0.15 \mathrm{a}$ & $0.98 \pm 0.19 b$ & $1.20 \pm 0.30 b$ & $2.02 \pm 0.17 \mathrm{a}$ \\
\hline & M1 & 0.00 & $0.00 \pm 0.21 \mathrm{c}$ & $0.00 \pm 0.26 c$ & $0.00 \pm 0.43 \mathrm{c}$ & $0.00 \pm 0.23 \mathrm{~d}$ \\
\hline & M2 & 2.00 & $0.65 \pm 0.21 b c$ & $0.75 \pm 0.26 \mathrm{c}$ & $1.15 \pm 0.43 \mathrm{c}$ & $1.06 \pm 0.23 \mathrm{c}$ \\
\hline & M3 & 2.50 & $1.05 \pm 0.21 b$ & $1.80 \pm 0.26 b$ & $2.90 \pm 0.43 b$ & $2.03 \pm 0.23 b$ \\
\hline & M4 & 3.00 & $3.50 \pm 0.21 \mathrm{a}$ & $3.45 \pm 0.26 \mathrm{a}$ & $5.30 \pm 0.43 \mathrm{a}$ & $3.01 \pm 0.23 \mathrm{a}$ \\
\hline
\end{tabular}

Stockings with a common letter are not significantly $(\mathrm{p}>0.05)$. 
The medium with $3.0 \mathrm{mg} / \mathrm{L}$ of 2,4-D in the species C. Nardus and C. Citratus obtained statistically equal callus amounts of 4.00 and 3.00 respectively, while $\mathrm{C}$. nardus in this same culture medium obtained greater amounts of shoots (4.70), plants (8.10) and lengths (3.73) surpassing the other culture media as shown in Table 3.4.

In Cuba, Quiala and Col; (2002) established cell suspensions from corns grown in semi-solid culture medium of Cymbopogon citratus (DC) Stapf, obtaining callus formation directly in liquid culture medium, which only took place in the leaf sheath cylinder closest to the meristematic zone. The same result was obtained in the two lemongrass species in the present investigation.

Table 3.4. Effect of 2,4-D on lemongrass embriogénesis

\begin{tabular}{lllllll}
\hline & Media & 2,4-D & Number of & Number of \\
Specie & culture & $(\mathrm{mg} / \mathrm{L})$ & calluses & Number of & $\begin{array}{l}\text { Plant } \\
\text { lengh }(\mathrm{cm})\end{array}$ \\
\hline Citratus & M1 & 0.00 & $0.00 \pm 0.29 \mathrm{c}$ & $0.00 \pm 0.37 \mathrm{c}$ & $0.00 \pm 0.60 \mathrm{c}$ & $0.00 \pm 0.33 \mathrm{e}$ \\
Citratus & M2 & 2.00 & $0.50 \pm 0.29 \mathrm{bc}$ & $0.40 \pm 0.37 \mathrm{c}$ & $0.80 \pm 0.60 \mathrm{c}$ & $0.56 \pm 0.33 \mathrm{de}$ \\
Citratus & M3 & 2.50 & $0.70 \pm 0.29 \mathrm{bc}$ & $1.30 \pm 0.37 \mathrm{bc}$ & $1.80 \pm 0.60 \mathrm{bc}$ & $1.25 \pm 0.33 \mathrm{cde}$ \\
Citratus & M4 & 3.00 & $3.00 \pm 0.40 \mathrm{a}$ & $2.20 \pm 0.37 \mathrm{~b}$ & $2.50 \pm 0.60 \mathrm{bc}$ & $2.28 \pm 0.33 \mathrm{cde}$ \\
Nardus & M1 & 0.00 & $0.00 \pm 0.29 \mathrm{c}$ & $0.00 \pm 0.37 \mathrm{c}$ & $0.00 \pm 0.60 \mathrm{c}$ & $0.00 \pm 0.33 \mathrm{e}$ \\
Nardus & M2 & 2.00 & $0.80 \pm 0.29 \mathrm{bc}$ & $1.10 \pm 0.37 \mathrm{bc}$ & $1.50 \pm 0.60 \mathrm{bc}$ & $1.55 \pm 0.33 \mathrm{bcd}$ \\
Nardus & M3 & 2.50 & $1.40 \pm 0.29 \mathrm{~b}$ & $2.30 \pm 0.37 \mathrm{~b}$ & $4.00 \pm 0.60 \mathrm{~b}$ & $2.81 \pm 0.33 \mathrm{ab}$ \\
Nardus & M4 & 3.00 & $4.00 \pm 0.29 \mathrm{a}$ & $4.70 \pm 0.37 \mathrm{a}$ & $8.10 \pm 0.60 \mathrm{a}$ & $3.73 \pm 0.33 \mathrm{a}$ \\
\hline
\end{tabular}

Stockings with a common letter are not significantly $(\mathrm{p}>0.05)$.

\subsection{In vitro Conservation of Lemongrass}

In the experiment of in vitro conservation of lemongrass, the variables were evaluated two, six and twelve months after the establishment and in this last evaluation at twelve months there was no survival of in vitro lemongrass plants.

In the two-month evaluation it can be seen in Table 4.5 that as the increase of mannitol in the culture medium increased, the survival of the explants of both lemongrass species increased. The M4 with $3.0 \mathrm{mg} / \mathrm{L}$ of mannitol in the C. nardus species reached the highest survival rate (97.50), followed by the same medium in the C. citratus species with $92.50 \%$ survival. With this medium the plants also reached a greater number of shoots and their length. Without mannitol in the culture medium, the plants did not survive within two months. This is explained because after fifteen days if the subculture is not done, the plants begin to deteriorate until they dry. 


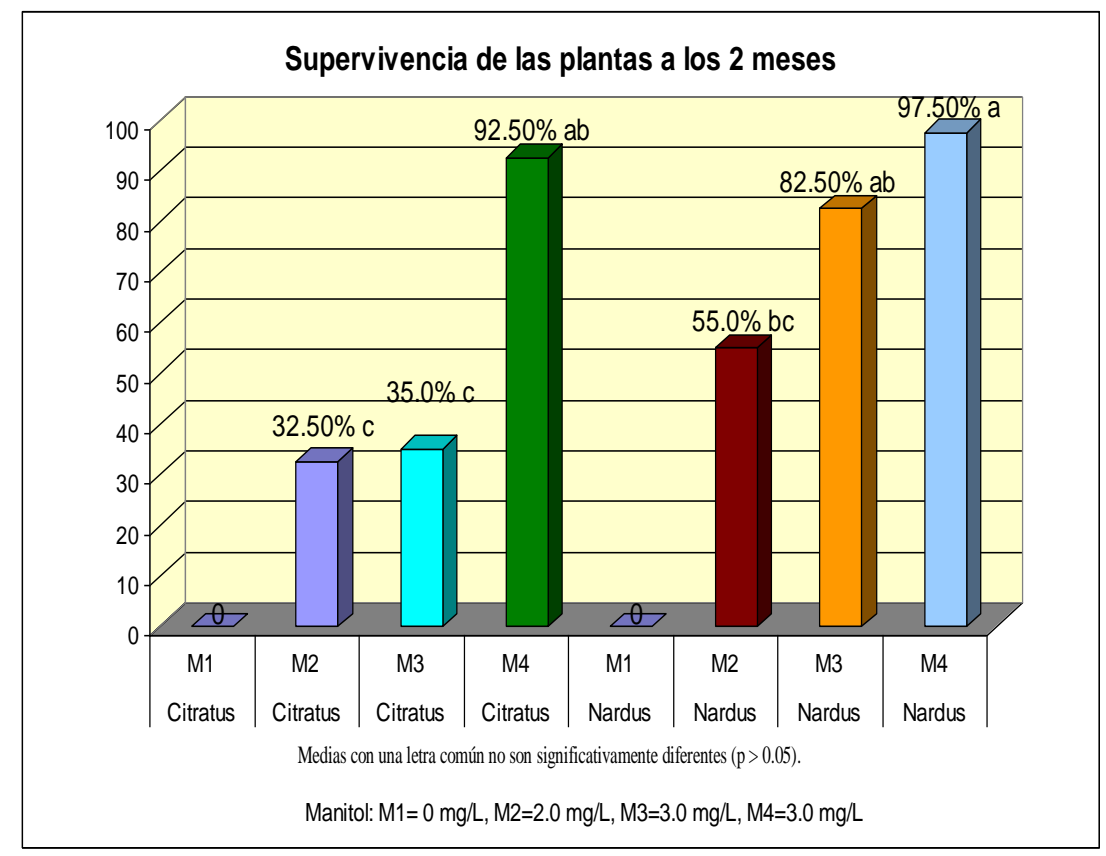

Figure 3.5 Influence of Mannitol at six months in Survival of Lemongrass plants.

Table 3.5 Individual Effect between Species and Culture Media in the in vitro conservation of lemongrass at 2 months

\begin{tabular}{lccccc}
\hline Specie & Culture & $\begin{array}{c}\text { Manitol } \\
(\mathrm{mg} / \mathrm{L})\end{array}$ & $\begin{array}{l}\text { Survival } \\
(\%)\end{array}$ & $\begin{array}{c}\text { Number } \\
\text { of shoots }\end{array}$ & $\begin{array}{c}\text { Plant lengh } \\
(\mathrm{cm})\end{array}$ \\
\hline Nardus & & & $58.75 \pm 3.20 \mathrm{a}$ & $3.03 \pm 0.19 \mathrm{a}$ & $0.69 \pm 0.06 \mathrm{a}$ \\
Citratus & & & $40.00 \pm 3.20 \mathrm{~b}$ & $1.70 \pm 0.19 \mathrm{~b}$ & $0.73 \pm 0.06 \mathrm{a}$ \\
& M4 & 30 & $95.00 \pm 4.53 \mathrm{a}$ & $5.05 \pm 0.27 \mathrm{a}$ & $1.12 \pm 0.08 \mathrm{a}$ \\
& M3 & 20 & $58.75 \pm 4.53 \mathrm{~b}$ & $2.65 \pm 0.27 \mathrm{~b}$ & $0.83 \pm 0.08 \mathrm{a}$ \\
& M2 & 15 & $43.75 \pm 4.53 \mathrm{~b}$ & $1.75 \pm 0.27 \mathrm{~b}$ & $0.89 \pm 0.08 \mathrm{a}$ \\
& M1 & 0 & $0.00 \pm 4.53 \mathrm{c}$ & $0.00 \pm 0.27 \mathrm{c}$ & $0.00 \pm 0.08 \mathrm{~b}$
\end{tabular}

Stockings with a common letter are not significantly $(\mathrm{p}>0.05)$. 
Vol. 5, No. 01; 2020

ISSN: $2456-8643$

Table 3.5 Effect of Mannitol as a growth inhibitor on the in vitro preservation of lemongrass at 2 months.

\begin{tabular}{lccccc}
\hline & & & & \\
Specie & Culture & Manitol & Survival & Number & Plant lengh \\
& & $(\mathrm{mg} / \mathrm{L})$ & $(\%)$ & of shoots & $(\mathrm{cm})$ \\
\hline Citratus & M1 & 0 & $0.00 \pm 6.40 \mathrm{~d}$ & $0.00 \pm 0.38 \mathrm{c}$ & $0.00 \pm 0.12 \mathrm{c}$ \\
Citratus & M2 & 15 & $32.50 \pm 6.40 \mathrm{c}$ & $1.30 \pm 0.38 \mathrm{c}$ & $0.83 \pm 0.12 \mathrm{bc}$ \\
Citratus & M3 & 20 & $35.00 \pm 6.40 \mathrm{c}$ & $1.40 \pm 0.38 \mathrm{c}$ & $0.60 \pm 0.12 \mathrm{bc}$ \\
Citratus & M4 & 30 & $92.50 \pm 6.40 \mathrm{ab}$ & $4.10 \pm 0.38 \mathrm{ab}$ & $1.48 \pm 0.12 \mathrm{a}$ \\
Nardu & M1 & 0 & $0.00 \pm 6.40 \mathrm{~d}$ & $0.00 \pm 0.38 \mathrm{c}$ & $0.00 \pm 0.12 \mathrm{c}$ \\
Nardus & M2 & 15 & $55.00 \pm 6.40 \mathrm{bc}$ & $2.20 \pm 0.38 \mathrm{bc}$ & $0.94 \pm 0.12 \mathrm{ab}$ \\
Nardus & M3 & 20 & $82.50 \pm 6.40 \mathrm{ab}$ & $3.90 \pm 0.38 \mathrm{ab}$ & $1.07 \pm 0.12 \mathrm{ab}$ \\
Nardus & M4 & 30 & $97.50 \pm 6.40 \mathrm{a}$ & $6.00 \pm 0.38 \mathrm{a}$ & $0.75 \pm 0.12 \mathrm{abc}$ \\
\hline
\end{tabular}

Stockings with a common letter are not significantly $(\mathrm{p}>0.05)$

Six months after re-evaluating the plants, there is a marked reduction in the survival of the plants, with the means with 3.00 and $2.50 \mathrm{mg} / \mathrm{L}$ of mannitol showing higher survival rates than in the other media with 46.0 and $30.0 \%$ in the C. nardus species (Table 3.6). The C. citratus species tends to deteriorate faster than the C. nardus species both in vitro and in situ. In an MS medium without osmoregulators such as growth inhibitor mannitol, this species should be transferred to fresh medium every 15 days.

The smallest reductions in the number of shoots and the length of the plants were achieved using the means with 15 and $30 \mathrm{mg} / \mathrm{L}$ of mannitol in the species C. Citratus but with the lowest survival of the explants with 32.50 and $35.0 \%$. The highest number of conserved plants (6.0) at 60 days was achieved with the medium containing $30 \mathrm{mg} / \mathrm{L}$ of mannitol in the species C. Nardus with the highest survival (97.50\%). Similar results were observed by Skalova et al; (2012) during the in vitro conservation of yacon (Smallanthus sonchifolius), except that the concentration of mannitol was 10 and $20 \mathrm{~g} / \mathrm{L}$ in MS medium. Bello et al; (2014) working with sugarcane in Mexico obtained that treatments with 15, 30 and $45 \mathrm{~g} / \mathrm{L}$ of mannitol showed survivals of 80,70 and $43 \%$ at 180 days and found no significant differences for the number outbreaks at the evaluated mannitol concentrations.. 


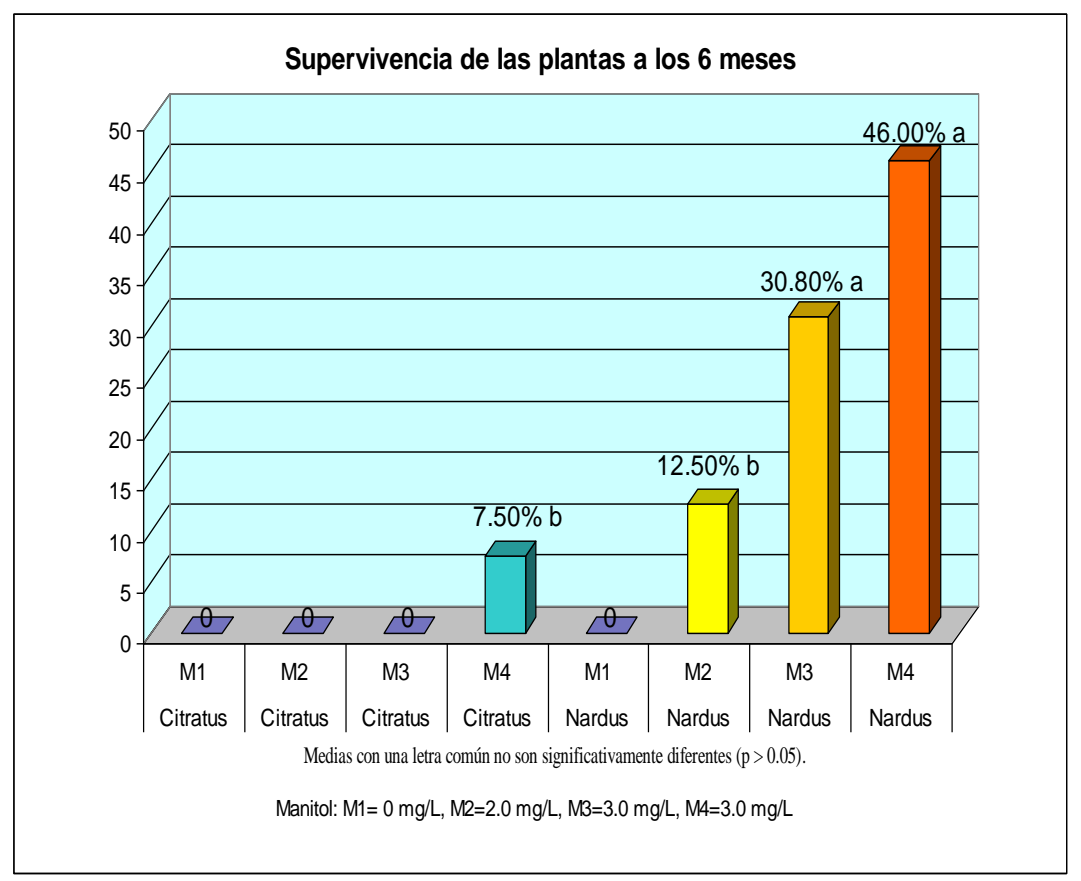

Figure 3.6 Influence of Mannitol at Six Months in the Survival of Lemongrass Plants.

Table 3.5 Individual Effect between Species and Culture Media in the In vitro Conservation of Lemongrass at 6 Months.

\begin{tabular}{lcccll}
\hline Specie & Culture & $\begin{array}{c}\text { Manitol } \\
(\mathrm{mg} / \mathrm{L})\end{array}$ & \multicolumn{1}{c}{$\begin{array}{c}\text { Survival } \\
(\%)\end{array}$} & Shoots /plant & \multicolumn{1}{l}{$\begin{array}{l}\text { Plant lengh } \\
(\mathrm{cm})\end{array}$} \\
\hline Nardus & & & $22.33 \pm 1.82 \mathrm{a}$ & $1.18 \pm 0.10 \mathrm{a}$ & $0.45 \pm 0.04 \mathrm{a}$ \\
Citratus & & & $1.88 \pm 1.82 \mathrm{~b}$ & $0.08 \pm 0.10 \mathrm{~b}$ & $0.06 \pm 0.04 \mathrm{a}$ \\
& M4 & 30 & $26.75 \pm 2.57 \mathrm{a}$ & $1.55 \pm 0.14 \mathrm{a}$ & $0.30 \pm 0.06 \mathrm{ab}$ \\
& M3 & 20 & $15.40 \pm 2.57 \mathrm{~b}$ & $0.70 \pm 0.14 \mathrm{~b}$ & $0.51 \pm 0.06 \mathrm{a}$ \\
& M2 & 15 & $6.25 \pm 2.57 \mathrm{bc}$ & $0.25 \pm 0.14 \mathrm{bc}$ & $0.21 \pm 0.06 \mathrm{bc}$ \\
& M1 & 0 & $0.00 \pm 2.57 \mathrm{c}$ & $0.00 \pm 0.14 \mathrm{c}$ & $0.00 \pm 0.06 \mathrm{c}$
\end{tabular}

Stockings with a common letter are not significantly $(\mathrm{p}>0.05)$. 
Vol. 5, No. 01; 2020

ISSN: $2456-8643$

Table 3.6 Effect of Mannitol as a growth inhibitor on in vitro conservation of lemongrass at 6 months.

Specie Culture Manitol Survival Shoots /plant Plant lengh
$(\mathrm{mg} / \mathrm{L})$
$(\%)$
$(\mathrm{cm})$

\begin{tabular}{llrlll}
\hline Citratus & M1 & 0 & $0.00 \pm 3.63 \mathrm{~b}$ & $0.00 \pm 0.20 \mathrm{c}$ & $0.00 \pm 0.09 \mathrm{c}$ \\
Citratus & M2 & 15 & $0.00 \pm 3.63 \mathrm{~b}$ & $0.00 \pm 0.20 \mathrm{c}$ & $0.00 \pm 0.09 \mathrm{c}$ \\
Citratus & M3 & 20 & $0.00 \pm 3.63 \mathrm{~b}$ & $0.00 \pm 0.20 \mathrm{c}$ & $0.00 \pm 0.09 \mathrm{c}$ \\
Citratus & M4 & 30 & $7.50 \pm 3.63 \mathrm{~b}$ & $0.30 \pm 0.20 \mathrm{c}$ & $0.23 \pm 0.09 \mathrm{bc}$ \\
Nardus & M1 & 0 & $0.00 \pm 3.63 \mathrm{~b}$ & $0.00 \pm 0.20 \mathrm{c}$ & $0.00 \pm 0.09 \mathrm{c}$ \\
Nardus & M2 & 15 & $12.50 \pm 3.63 \mathrm{~b}$ & $0.50 \pm 0.20 \mathrm{c}$ & $0.42 \pm 0.09 \mathrm{~b}$ \\
Nardus & M3 & 20 & $30.80 \pm 3.63 \mathrm{a}$ & $1.40 \pm 0.20 \mathrm{~b}$ & $1.01 \pm 0.09 \mathrm{a}$ \\
Nardus & M4 & 30 & $46.00 \pm 3.63 \mathrm{a}$ & $2.80 \pm 0.20 \mathrm{a}$ & $0.37 \pm 0.09 \mathrm{bc}$ \\
\hline
\end{tabular}

Stockings with a common letter are not significantly $(\mathrm{p}>0.05)$.

The reduction in the number of shoots and the length of the plants was achieved using the medium with $3.0 \mathrm{mg} / \mathrm{L}$ of mannitol in the species C. Citratus with $7.50 \%$ survival. The greatest number of plants conserved at 180 days was achieved with the medium containing $30 \mathrm{mg} / \mathrm{L}$ of mannitol in the species C. Nardus with the greatest survival (46\%).

\section{CONCLUSIONS}

The establishment of two lemongrass species (C. citratus and C. nardus) was achieved in vitro through biotechnological techniques.

Surviving outbreaks in all treatments of organogenesis, embryogenesis and in vitro conservation of lemongrass, produced roots and showed $85 \%$ survival during the acclimatization stage. The acclimatized vitro plants had a vigorous appearance and developed normally when they were transferred to the soil.

The reduction in height and presence of axillary outbreaks observed in mannitol treatments would be of interest for in vitro conservation, and it is concluded that the use of mannitol may be a new alternative for in vitro conservation of the germplasm of these species.

Lemongrass plants were preserved in vitro under conditions of slow growth caused by manitoll, which retarded growth without affecting survival. Therefore, this system allows to maintain viable germplasm collections with a minimum investment of time and resources. 
Vol. 5, No. 01; 2020

ISSN: $2456-8643$

Lemongrass plants preserved in vitro can be transferred to multiplication culture medium to obtain an unlimited source of plant material required for the establishment of a plant bank, germplasm exchange or genetic improvement programs.

\section{Acknowledgement}

To the Ministry of Higher Education, Science and Technology (MESCYT) / National Fund for Innovation in Scientific and Technological Development (FONDOCyT) for the financing of this project. Thanks to the Institute of Innovation in Biotechnology and Industry (IIBI) and all the team that got involved in this research.

\section{REFERENCES}

Antolinez, G. J. C; De Colmenares, N. G; Usubillaga, A; Darghan, E. and Linares, S. (2008). Evaluation of Agronomic Variables in the Cultivation of Limonaria (Cymbopogon citratus stapf) for the Production of Essential Oil. Interciencia, September, year / vol. 33, number 009. Interciencia Association, Caracas, Venezuela pp. 693-699. Accessed 04-07-2010.

Bello-Bello, J; Poot-Poot, W; Iglesias-Andreu, L; Caamal-Velázquez, H. and Diaz-Sanchez, M. (2014). Comparison of the Effect of Osmoregulators and Growth Inhibitors on the In Vitro Conservation of Sugar Cane. Published as Article in Agrociencia 48: 439-446. 2014. Mexico.

Cetz, L. J. (2005). Micropropagation of Sweet Chile (Capsicum annuum L. var. Najera.) And Habanero Chile (Capsicum chinense Jacq.) With a view to the Genetic Improvement of the Cultivation. Tropical Agronomic Center for Research and Teaching (CATIE). Turrialba, Costa Rica.

Chalchat, J. C., Garry, R. F., Menut, C., Lamaty, G., Malhuret, R. and Chopineau, J. (1997). Correlation Between Chemical Composition and Antimicrobial Activity. SAW. Activity of some African Essential Oils. J. Essent Oil

Cuéllar, J. M. (1996). In vitro vegetative propagation from Young Sugarcane Leaves (Saccharum officinarum L.). Catholic University of the West (UNICO), Santa Ana, El Salvador. Mesoamerican Agronomy. Res. 9: 67-75.

García, A. L; Pérez Ponce, J. N; Rodríguez, U. M; Pérez, B; Martínez, P.Y. and Zoe Sarria Hernández, Z. S. (2004). Conservation of cane germplasm (Saccharum officinarum L.). Plant Biotechnology Institute. Central University Marta Abreu "of Las Villas. Road to Camajuaní, Villa Clara. Cuba CP 54830. e-mail. legarcia@ibp.co.cu Plant Biotechnology Vol. 4, No. 2: 101105.

Licea, M. R. J., Maité, F. M., Karen, A. R. and Gómez, R. K. (2001). Influence of the Agar Concentration on the In Vitro Multiplication of Cymbopogon citratus (D. C.) Stapf. Center for Plant Biotechnology Studies, University of Granma. Aptdo 21, Bayamo, Granma. CP 85100, Cuba. Scientific article. Plant biotechnology Vol. 1 No. 2: 77-81, May-August 2001. 
Mohd, I. N; Fomda, B. A; Jaykumar, E. and Bhat, J. A. (2010). Antibacterial Activity of Lemongrass (Cymbopogon citratus) Oil Against Some Selected Pathogenic Bacteria. Allahabad Agricultural Institute-Deemed University Allahabad (UP) India. Asian Pacific Journal of Tropical Medicine Volume 3, Issue 7, Pages 535-538.

Murashige, T. Skoog, F. 1962. A Revised Medium for Rapid Growth and Bioassays with Tobacco Tissue Cultures. Physiology Plantarum 15: 473-497.

Olmos, S; Luciani, G. and Galdeano, E. (2004). Micropropagation Part V. Methods of Propagation and Conservation of Germplasm. In: Echenique, V; Rubinstein C and Mroginski, L. (eds.). Biotechnology and Plant Improvement. (Ed): INTA, Buenos Aires, Argentina, pp. 163178.

Roig, T. J. (2002). Cultivation Technical Instructions for Cymbopogon citratus (D.C) Stapf (Caña Santa). Rev. Cuba Plant Med Vol. 7, 02.

Skalova, I., I. Viehmannova, and J. Vitamvas. (2012). In vitro Conservation of Smallanthus sonchifolius Under slow-growth Conditions. Agr. Trop Subtrop 45: 147-150.

Vásquez Tineo, M. and Ramírez, Maritza. (2008). Phytochemical and Prospection Study of the Potential Bioinsecticide Properties of Nine Vegetable Species in the Dominican Republic. Pharmaceutical Biotechnology of Natural Products of the Institute of Innovation in Biotechnology and Industry (IIBI), Santo Domingo. Dominican Republic.

Watson, L. and Dallwitz, M. J. (2008). The Grass Genera of the World. Retrieved on 01-262010.

Wyse Jackson, P. S. \& Sutherland, L.A. (2000). International Agenda for Conservation in Botanical Gardens. International Organization for Conservation in Botanical Gardens (BGCI), U.K. 